\section{Lifecycle Impacts of Structural Frame Materials for Multi-storey Building Systems}

\section{Ambrose Dodoo}

Department of Building Technology, Linnaeus University, Växjö, SE-35195, Sweden

Corresponding author: ambrose.dodoo@lnu.se

$\Gamma$ crossef http://dx.doi.org/10.5755/j01.sace.24.1.22081

In this study the lifecycle primary energy and greenhouse gas (GHG) implications of multi-storey building versions with different structural frame materials as well as construction systems are analysed considering flows from the production, operation and end-of-life phases and the full natural resources chains. The analysed building versions include conventional and modern construction systems with light-frame timber, reinforced concrete-frame, massive timber frame, beam-and-column timber frame or modular timber frame structural systems and are designed to the energy efficiency level of the passive house criteria. The results show that the lifecycle primary energy use and GHG emissions for the reinforced concrete building system are higher than those for the timber-based building systems, due primarily to the lower production primary energy use and GHG emissions as well as greater amount of biomass residues when using wood-based materials. The operation primary energy use and GHG emission for the buildings are lower when heated with cogenerated district heating compared to when heated with electric-based heat pump, showing the significance of heat supply choice. The findings emphasize the importance of structural frame material choice and system-wide lifecycle perspective in reducing primary energy use and GHG emissions in the built environment.

Keywords: building frame material, concrete, life cycle analysis, passive house, timber.

Of the global primary energy supply of $576.1 \mathrm{EJ}$ in 2016 , fossil fuels constituted $81.1 \%$, with oil, coal and fossil gas representing 31.9\%, 27.1\% and 22.1\%, respectively (IEA, 2018a). According to the BP's evolving transition scenario which assumes the global energy system may develop in similar manner as the recent past, global total primary energy use may increase about 35\% between 2016 and 2040, with fossil fuels contributing 74\% of the total primary energy supply in 2040 (BP, 2018). Fossil fuel combustion is a major source of greenhouse gas $(\mathrm{GHG})$ emissions and together with industrial processes linked mainly to cement manufacture accounted for $65 \%$ of the global anthropogenic GHG emissions in 2010 (IPCC, 2014). A growing body of evidence indicates that increasing atmospheric concentration of GHGs is altering the global climate system (IPCC, 2014).

Globally, the building and construction sectors account for $36 \%$ of the total final energy use and for about $40 \%$ of the total $\mathrm{CO}_{2}$ emissions (IEA, 2018b). The sectors are suggested to offer significant opportunities to reduce fossil fuels use and thereby shift to a low-carbon built environment (IPCC, 2014). A variety of measures may be deployed to improve energy performance of buildings, including improved thermal envelope insulation and airtightness, high performance windows, efficient technical equipment and supply systems, and use of less energy-intensive building mate-

\section{Introduction}

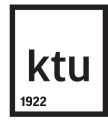

Journal of Sustainable Architecture and Civil Engineering Vol. 1 / No. 24 / 2019 pp. $17-28$ DOI 10.5755/j01.sace.24.1.22081 
rials. Lifecycle analysis considering the entire energy and material chains can play an important role in identifying options to reduce energy use and climate impacts of buildings.

Lifecycle analyses of buildings in cold climates show that the operation phase typically dominates the energetic and climatic impacts while the production phase constitutes a significant share of the impacts for low-energy buildings (Cabeza et al., 2014, Thormark, 2002). Ramesh et al. (2010) reviewed lifecycle analysis studies of 73 conventional and low-energy buildings from 13 countries and noted the production phase to account for $10-20 \%$ of the buildings' total lifecycle energy use. For a low-energy building, Thormark (2002) showed that the share of the total lifecycle energy used for production reaches about $45 \%$. The significance of material choice and the role of building systems in reducing overall lifecycle impacts of buildings are discussed and explored in some recent studies (e.g. Gustavsson and Sathre, 2006, Tettey et al., 2014). Tettey et al. (2014) found that total production primary energy use is reduced $6-7 \%$ while $\mathrm{CO}_{2}$ emission is reduced $7-8 \%$, when using an alternative insulation material to achieve the same energy performance for multi-storey buildings. Synthesis of research presented by the IPCC (2014) indicates that timber-based building systems results in lower production energy than conventional concrete-based alternatives while concrete-based building systems entail lesser production energy than steel-based alternatives. Suzuki et al. (1995) calculated the carbon emissions for construction of wood-frame, lightweight steel-frame and reinforced concrete-frame buildings to be 250,400 and $850 \mathrm{~kg} \mathrm{CO} / \mathrm{m}^{2}$, respectively.

Studies have analysed lifecycle energy and GHG impacts of buildings considering different activities and flows e.g. (Aye et al., 2012, Gustavsson et al., 2010, Dahlstrøm et al., 2012). Aye et al. (2012) considered the production and operation phases in a lifecycle energy and GHG analysis for three Australian multi-storey building systems. Gustavsson et al. (2010) calculated the primary energy use and $\mathrm{CO}_{2}$ emissions of an eight-storey modern wood-frame building, considering the production, operation and end-of-life phases. Dahlstrøm et al. (2012) conducted lifecycle assessment of a single-storey residential building designed to the Norwegian TEK 10 building code or passive house criteria, taking into account the production, operation, maintenance, and end-of-life waste treatment. They found that the passive building results in substantial reduction of primary energy use and GHG emissions compared to the code-compliant building. Most studies as above analysed conventional building systems while few studies have explored modern building systems. Fewer analyses have compared the lifecycle primary energy use and GHGs emission of conventional and modern building construction systems with different materials, and considering all lifecycle activities.

Here we investigate lifecycle primary energy use and GHGs emission of multi-storey buildings with different building construction systems for Norwegian conditions, considering flows from the production, operation and end-of-life phases of the buildings. The present study explores conventional and modern building systems designed to the Norwegian passive house criteria with reinforced concrete or timber structural frame materials.

An existing four-story residential building (Fig. 1) with a total heated floor area of $1140 \mathrm{~m}^{2}$ is used as reference to explore the implications of five different building systems. The building has conventional light timber framing structural system comprising studs and joist and foundation made of reinforced concrete. It has elevator besides a stairwell, and contains 16 apartments with living areas ranging from 42 to $78 \mathrm{~m}^{2}$. The façades are made of stucco and wood panelling, and 8 of the apartments have balconies, at the longitudinal ends of the building.

A functionally equivalent version of the building is designed using conventional reinforced concrete framing structural system and is documented in Persson (1998). For this variant, prefab reinforced concrete replaces the light timber joists floors as well as the load-bearing timber studs and walls while the stucco and wood panelling at the façades are replaced with cement render. 


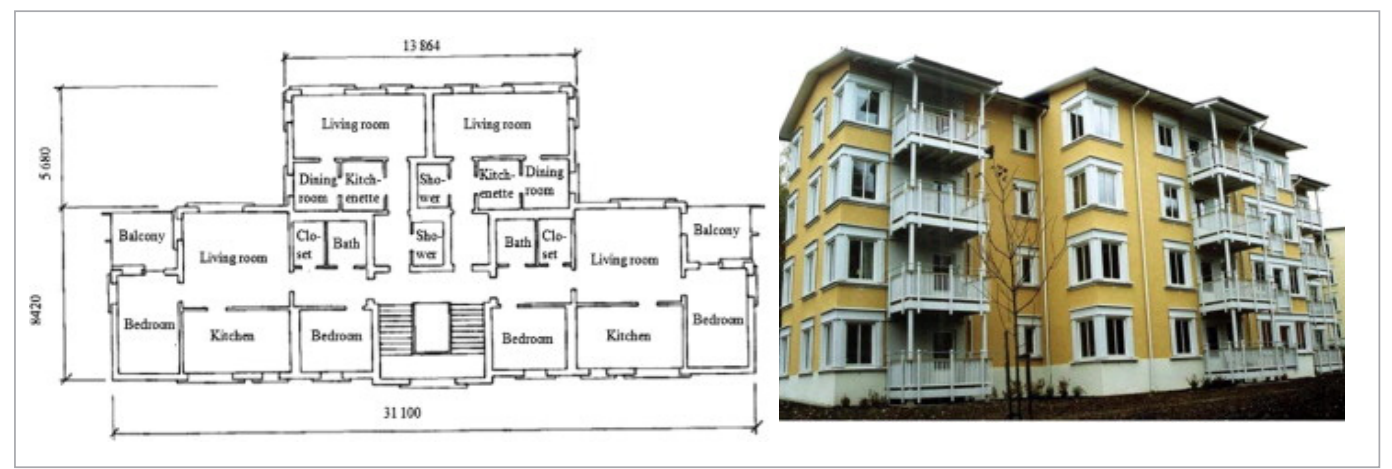

Fig. 1

Typical floor plan (left) and photograph (right) of the reference, built light-timber frame building

Besides the conventional light timber-frame and reinforced concrete-frame building versions, additional three modern functionally equivalent timber-frame versions of the reference building are designed with massive timber, beam-and-columns, and prefab modular structural elements, so that five building and construction systems are achieved. The massive timber building system has walls, floors and structural systems as well as load-bearing interior elements constructed with cross laminated timber (CLT). For the building with beam-and-column structural system, laminated veneer lumber ( $\mathrm{LVL}$ ) and glulam columns and beams are used as the main structural framework to transfer all horizontal and vertical loads to the foundation. The timber modular system is based on individual volumetric light-frame elements prefabricated off-site and transported to the building site.

All five building systems are modelled to fulfil the energy requirements of the Norwegian passive house criteria (NS 3700, 2013). Table 1 summarizes the thermal characteristics of the buildings while Table 2 gives inventory of key construction materials for the finished building systems excluding materials for cabinets, electrical services equipment and heating systems. All the buildings have efficient water taps based on current best available technology (BAT) and mechanical ventilation with heat recovery (MVHR) systems, with $82 \%$ heat recovery efficiency. For all building systems, the foundations consist of 120-160 mm reinforced concrete slab-on-ground and a 300$350 \mathrm{~mm}$ layer of expanded polystyrene (EPS) insulation laid on $150 \mathrm{~mm}$ crushed stones. For the beam-and-columns timber building system, the foundation also includes reinforced concrete footings besides the concrete slab-on-ground to take up concentrated point loads. The configuration of the modular system results in a slightly more floor area compared to the four other systems. Otherwise all the five building systems have the same architectural details. Fig. 2 presents illustrations of structural elements of the five studied building system versions. Reinforced concrete-based ele-

\begin{tabular}{l|c|c|c|c|c}
\hline \multicolumn{1}{|c|}{ Description } & $\begin{array}{c}\text { Reinforced } \\
\text { concrete } \\
\text { frame }\end{array}$ & $\begin{array}{c}\text { Light-frame } \\
\text { timber } \\
\text { frame }\end{array}$ & $\begin{array}{c}\text { Massive timber } \\
\text { frame }\end{array}$ & $\begin{array}{c}\text { Beam \& column } \\
\text { timber frame }\end{array}$ & $\begin{array}{c}\text { Modular } \\
\text { timber frame }\end{array}$ \\
\hline U-value $\left(\mathrm{W} / \mathrm{m}^{2} \mathrm{~K}\right)$ : & 0.08 & 0.08 & 0.08 & 0.08 & 0.08 \\
\hline Roof & 0.113 & 0.113 & 0.104 & 0.11 & 0.111 \\
\hline External wall & 0.161 & 0.161 & 0.16 & 0.215 & 0.196 \\
\hline Separating wall & 0.135 & 0.135 & 0.127 & 0.13 & 0.135 \\
\hline Internal floors & 0.8 & 0.8 & 0.8 & 0.8 & 0.8 \\
\hline Windows & 0.8 & 0.8 & 0.8 & 0.8 & 0.8 \\
\hline Doors & 0.108 & 0.108 & 0.108 & 0.108 & 0.108 \\
\hline Ground Floor & 0.3 & 0.3 & 0.3 & 0.3 & 0.3
\end{tabular}

Table 1

Thermal characteristics of the building systems 
Table 2

Mass (tonnes) of key materials for the building systems

\section{Fig. 2}

Illustrations of structural elements of the conventional (top) and modern construction systems (bottom)

\begin{tabular}{l|c|c|c|c|c}
\hline \multicolumn{1}{|c|}{ Material } & $\begin{array}{c}\text { Reinforced } \\
\text { concrete frame }\end{array}$ & $\begin{array}{c}\text { Light-frame } \\
\text { timber frame }\end{array}$ & $\begin{array}{c}\text { Massive timber } \\
\text { frame }\end{array}$ & $\begin{array}{c}\text { Beam \& column } \\
\text { timber frame }\end{array}$ & $\begin{array}{c}\text { Modular } \\
\text { timber frame }\end{array}$ \\
\hline Concrete & 1361 & 232 & 115 & 180 & 115 \\
\hline Iron/steel & 25 & 16 & 5 & 13 & 4 \\
\hline Lumber & 44 & 70 & 48 & 25 & 62 \\
\hline Particle board & 17 & 18 & 6 & 3 & 21 \\
\hline Plywood & 20 & 21 & 7 & - & 10 \\
\hline Laminated wood floor & - & - & 5 & 5 & 5 \\
\hline CLT & - & - & 55 & 5 & 5 \\
\hline LVL & - & - & - & 61 & - \\
\hline Glulam & - & - & 20 & 25 & 8 \\
\hline Insulation & 27 & 38.8 & 19.1 & 25.1 & 22.1 \\
\hline Plasterboard & 26 & 90.4 & 72 & 99 & 105 \\
\hline PVC \& polyurethane & 2 & 1.9 & 4.7 & 4.4 & 5.4 \\
\hline Mortar & 23 & 25 & 18 & 11 & 11 \\
\hline
\end{tabular}

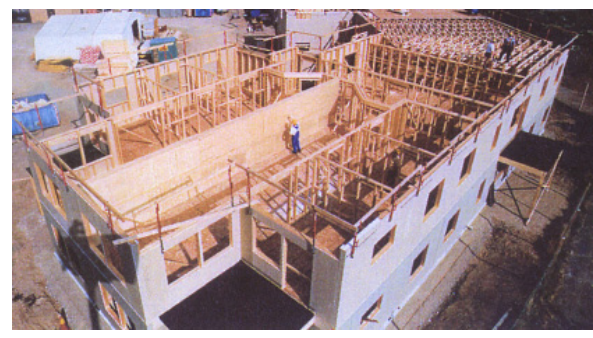

(a) Light timber-frame

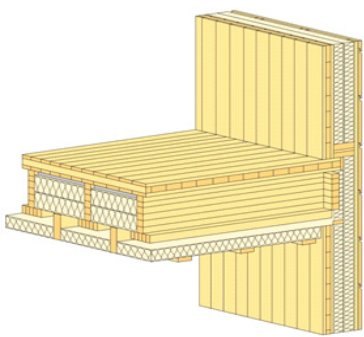

(c) Massive timber frame

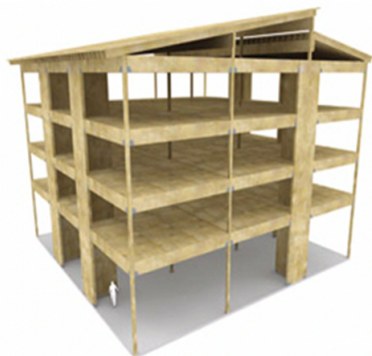

(d) Beam \& column timber frame

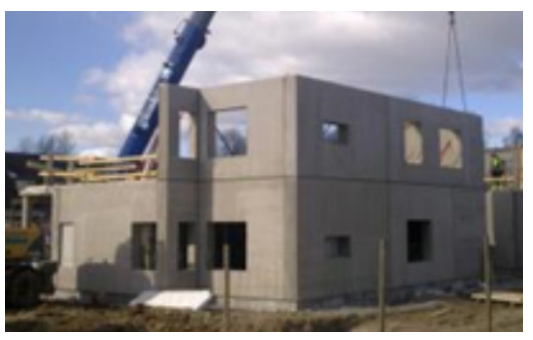

(b) Reinforced concrete-frame

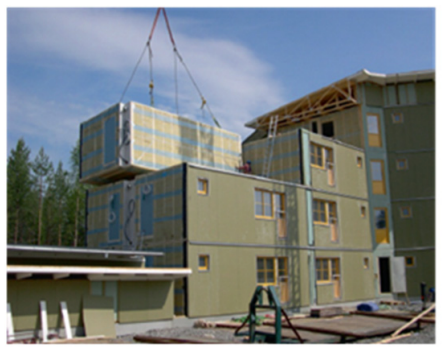

(e) Modular timber frame

vator shaft is used in the beam-and-column timber and reinforced concrete building systems while wood-constructed elevator shaft is used in the other timber-based building systems. In contrast to the other timber-based building systems, the light-frame and beam-and-column systems require greater amounts of concrete and steel reinforcement for the foundations.

Methods

Lifecycle studies with attributional- or consequential-based approach are noted in literature. While attributional-based approach mainly characterizes the direct flows linked to a system, typically using average data, consequential-based approach characterizes the system-wide impact of change considering direct and induced effects, typically using marginal data. Thus the approach used influence definition of the system boundary and data used in a lifecycle study. Using both at- 
tributional- and consequential-based approaches, Kua and Kamath (2014) modelled the lifecycle implications of replacing concrete with bricks and obtained significantly different results for the approaches. Plevin et al. (2014) noted that the two approaches may provide different perspectives and suggested that consequential-based approach can facilitate identification of robust options in the context of climate change mitigation. In this study a consequential-based approach with system perspective is used and the system boundary is defined to include flows in the production, operation and end-of-life stages of the buildings. The functional unit of the analysis is defined at the complete building level and the primary energy use and GHG emissions are expressed in terms of the heated building floor areas.

\section{Production phase}

This study used bottom-up models to quantify the production primary energy use of the buildings considering the full natural resource chains, and to track the GHG emissions from fossil fuels combustion and cement process reactions. Biomass residues from the wood product chain are increasingly used as bioenergy and the role of bioenergy in the Norwegian energy system is suggested to be strengthened (Bergseng et al., 2013). This study quantified the potential energy and GHG related benefits that can be derived from recoverable biomass residues from the wooden material chain.

A method suggested by Gustavsson et al. (2006) is used to calculate the production primary energy and GHG balances of the studied buildings. The primary energy used to extract, process, transport and assemble the materials is calculated, as well as the lower heating values of the logging, processing and construction biomass residues. The GHG emissions from fossil fuel combustion and cement process reactions are calculated, as well as the potential emissions avoided by replacing fossil fuel with recovered forest and processing residues. Recoverable forest residues at harvest are based on data from Gustavsson and Sathre (2006). Based on Gustavsson and Sathre (2006), 70\% recovery of available harvest residues and $100 \%$ of processing and construction residues are assumed. The assumed lower heating values for the recovered biomass are $4.25 \mathrm{kWh}$ / $\mathrm{kg}$ dry biomass for bark and harvest residues, $4.62 \mathrm{kWh} / \mathrm{kg}$ dry biomass for processing residues, and $5.17 \mathrm{kWh} / \mathrm{kg}$ dry biomass for recovered post-use wood (Gustavsson and Sathre, 2006). The amount of diesel fuel used for biomass recovery, expressed in terms of the heating value of the biomass, is assumed to be 1\% for processing residues and $5 \%$ for harvest residues (Gustavsson and Sathre, 2006). Specific final energy for building material production is based on data from Norwegian sources (Fossdal, 1995) as well as Ecoinvent (2012). These are supplemented with closely related data (Björklund and Tillman, 1997). The primary energy use is computed assuming fuel cycle energy inputs of 10\% for coal, and $5 \%$ for oil and natural gas, based on Gustavsson et al. (2010). For the electricity to manufacture the materials, $95 \%$ is assumed to be covered by a standalone biomass-fired steam turbine (BST) base-load plant, with light-oil gas turbines covering the remainder as peak-load. The conversion efficiencies of the BST plant and the light-oil gas turbines plants are assumed to be $40 \%$ and $34 \%$, respectively. Electricity distribution loss is assumed to be $2 \%$. The fuel-cycle carbon intensity of the fossil fuels are assumed to be 30,22 and $18 \mathrm{~kg} \mathrm{C} / \mathrm{kWh}$ end-use fuel for coal, oil, and fossil gas, respectively (Gustavsson and Sathre, 2006). The biogenic carbon storage sequestered or released from wood materials is not included in the inventory as the wood is assumed to come from sustainably managed forestry, where carbon flows out of the forest are balanced at the landscape level by carbon uptake by growing trees.

The primary energy and GHG for on-site construction and assembly are typically small compared to those for material production (Gustavsson et al., 2010), and depend on different factors including the type of construction material used and building system. Adalberth (2001) estimated the building construction energy to constitute $4 \%$ of the energy for material production and transport for the reference building. This percentage is applied to the studied building systems due to data constraints 
for each of the systems. Based on the estimated on-site construction and assembly primary energy use, we calculated the associated GHG emission assuming that half of the energy used, counted as primary energy use, is electricity-based, and other half is fossil fuel (diesel)-based.

\section{Operation phase}

The annual operation final energy use for space heating, ventilation, domestic hot water heating and household electricity provisions for the buildings are calculated hour-by-hour with the VIP-Energy program (Strusoft, 2010). The space heating demands of the buildings are calculated for the climate of Oslo (lat. 59.54' N; long. 1045' E), with assumed indoor temperatures of 22 and $18^{\circ} \mathrm{C}$ in the living and common areas of the buildings, respectively. The climate dataset of Oslo for the period 2000-2009 is used for the calculations and the maximum, average and minimum annual outdoor temperatures during this period were 26,9 and $-9{ }^{\circ} \mathrm{C}$, respectively. The internal heat gains from persons and electric process or activities within the buildings are based on default values in the VIP-Energy program and are $1.16 \mathrm{~W} / \mathrm{m}^{2}$ heat from persons and $4.3 \mathrm{~W} / \mathrm{m}^{2}$ from processes including electrical appliances and lighting.

Based on the operation final energy use, we calculate the operation primary energy use and GHG emissions using the ENSYST software (Karlsson, 2003). This software estimates primary energy use and GHG emission taking into account the entire energy chain from natural resources extraction to supply of final energy. We consider two different end-use heating systems: bedrock heat pump or district heating. For the heat pump, $95 \%$ of the electricity is assumed to be supplied from stand-alone BST plant and the remaining from light-oil gas turbine. The district heating is assumed to be supplied from combined heat and power (CHP) plant and heat-only boilers (HOB). As the CHP plant cogenerates heat and electricity, an allocation issue may arise. In this study we use the subtraction method to calculate the primary energy use for heat, considering the cogenerated electricity to replace electricity that would instead have been produced in a stand-alone plant using the same fuel and technology as the CHP plant (Gustavsson and Karlsson, 2006). The primary energy used for the replaced electricity in the stand-alone plant is subtracted from the CHP plant to obtain the primary energy for the heat (Gustavsson and Karlsson, 2006).

\section{End-of-life phase}

The end-of-life analysis is based on a methodology developed by Dodoo et al. (2009) and accounts for the energy and GHG flows associated with the demolition, transportation and processing of the post-use materials. The primary energy use and fossil GHG emissions avoided due to end-of-life material management are considered in the calculations. Based on Dodoo et al. (2009), 90\% of the demolished concrete, steel and wood materials are assumed to be recovered or recycled. The demolished concrete is assumed to be crushed into aggregate followed by exposure to air for a 4-month period to increase carbonation uptake of $\mathrm{CO}_{2}$. The recycled aggregate is assumed to be used for below-ground filling applications, substituting virgin aggregate. The post-use steel is assumed to be recycled as feedstock for production of new scrap-based steel reinforcement. The demolished wood is assumed to be recovered of energy through combustion, replacing fossil coal.

\section{Complete lifecycle}

The total primary energy use and GHG emissions for the buildings are calculated for a 50 -year period.

The primary energy for material production for the studied building systems, including the energy for extraction, processing and transportation, are shown in Table 3, divided into different end-use energy carriers: fossil fuels, biomass and electricity. Positive numbers denote energy use and negative numbers denote energy that is available from recovered biomass residues. The total production primary energy balances for the building systems are also shown (in Table 3 ) and is lowest for the massive timber building and greatest for the reinforced concrete building. 


\begin{tabular}{|c|c|c|c|c|c|}
\hline \multirow[b]{2}{*}{ Description } & \multicolumn{5}{|c|}{ Primary energy $\left(\mathrm{kWh} / \mathrm{m}^{2}\right)$} \\
\hline & $\begin{array}{l}\text { Reinforced } \\
\text { concrete }\end{array}$ & $\begin{array}{l}\text { Light-frame } \\
\text { timber }\end{array}$ & $\begin{array}{l}\text { Massive } \\
\text { timber }\end{array}$ & $\begin{array}{l}\text { Beam-and- } \\
\text { column timber }\end{array}$ & $\begin{array}{c}\text { Modular } \\
\text { timber }\end{array}$ \\
\hline \multicolumn{6}{|l|}{ Material production } \\
\hline Fossil fuels & 480 & 401 & 332 & 389 & 377 \\
\hline Electricity & 306 & 233 & 220 & 271 & 265 \\
\hline Bioenergy & 26 & 42 & 112 & 115 & 56 \\
\hline Total & 812 & 676 & 664 & 775 & 698 \\
\hline \multicolumn{6}{|l|}{ Building construction } \\
\hline Fossil fuel & 16 & 14 & 13 & 16 & 14 \\
\hline Electricity & 16 & 14 & 13 & 16 & 14 \\
\hline Total & 32 & 28 & 26 & 32 & 28 \\
\hline Production primary energy use & 844 & 704 & 690 & 807 & 726 \\
\hline \multicolumn{6}{|l|}{ Biomass residue recovery } \\
\hline Forest harvest & -103 & -150 & -252 & -227 & -153 \\
\hline Wood processing & -218 & -341 & -691 & -619 & -344 \\
\hline Construction & -35 & -48 & -63 & -55 & -48 \\
\hline Total & -356 & -539 & -1005 & -901 & -546 \\
\hline Production primary energy balance & 448 & 165 & -315 & -94 & 180 \\
\hline
\end{tabular}

Table 3

Production primary energy balances for the building systems

\begin{tabular}{|c|c|c|c|c|c|}
\hline \multirow[b]{2}{*}{ Description } & \multicolumn{5}{|c|}{ GHG balance $\left(\mathrm{Kg} \mathrm{CO}_{2} / \mathrm{m}^{2}\right)$} \\
\hline & $\begin{array}{l}\text { Reinforced } \\
\text { concrete }\end{array}$ & $\begin{array}{c}\text { Light-frame } \\
\text { timber }\end{array}$ & $\begin{array}{l}\text { Massive } \\
\text { timber }\end{array}$ & $\begin{array}{l}\text { Beam-and- } \\
\text { column timber }\end{array}$ & $\begin{array}{c}\text { Modular } \\
\text { timber }\end{array}$ \\
\hline \multicolumn{6}{|l|}{ Material production } \\
\hline Fossil fuels & 161 & 126 & 103 & 120 & 116 \\
\hline Electricity & 12 & 9 & 9 & 11 & 10 \\
\hline Net cement reaction ${ }^{a}$ & 75 & 15 & 8 & 11 & 7 \\
\hline Total & 248 & 150 & 120 & 142 & 133 \\
\hline \multicolumn{6}{|l|}{ Building construction } \\
\hline Fossil fuel & 5 & 5 & 4 & 5 & 5 \\
\hline Electricity & 1 & 1 & 1 & 1 & 1 \\
\hline Total & 6 & 6 & 5 & 6 & 6 \\
\hline Total production $\mathrm{CO}_{2}$ emission & 254 & 156 & 125 & 148 & 139 \\
\hline \multicolumn{6}{|l|}{ Carbon avoided, stock and flow } \\
\hline Forest harvest biomass residues & -39 & -56 & -95 & -85 & -58 \\
\hline Wood processing biomass residues & -78 & -122 & -248 & -223 & -124 \\
\hline Construction biomass residues & -13 & -17 & -23 & -20 & -17 \\
\hline Residues recovery (fossil fuel used) & 3 & 5 & 7 & 6 & 5 \\
\hline Total & -127 & -190 & -359 & -322 & -194 \\
\hline Production carbon balance & 127 & -34 & -234 & -174 & -55 \\
\hline
\end{tabular}

Table 4

Production GHG balances for the building systems

a Net cement reaction is the calcination emission minus carbonation uptake for the 50-year service-life

Table 4 shows the production GHG balances for the building system versions including flows to the atmosphere (positive numbers) and emission avoided (negative numbers). The net cement reaction is the calcination emission minus carbonation uptake during the 50-year service-life. 
The increase in material production GHG emission of the reinforced concrete building system compared to the timber building systems ranges from $40 \%$ to $52 \%$.

Table 5 presents the annual final operation energy for the building systems, including space heating, tap water heating, ventilation electricity and household and facility electricity. Household electricity dominates the buildings' final operation energy use. The space heating demand for the concrete-frame building is slightly lower than those for the timber-based alternatives due to the thermal mass effect.

Table 5

Annual final energy use for operation of the buildings located in Oslo
Table 6

Annual primary energy use and GHG emission of the buildings located in Oslo

\begin{tabular}{l|c|c|c|c|c}
\hline \multirow{2}{*}{\multicolumn{1}{|c|}{ Description }} & \multicolumn{5}{|c}{ Final energy use $\left(\mathrm{kWh} / \mathrm{m}^{2} /\right.$ year $)$} \\
\cline { 2 - 6 } & $\begin{array}{c}\text { Reinforced } \\
\text { concrete }\end{array}$ & $\begin{array}{c}\text { Light-frame } \\
\text { timber }\end{array}$ & $\begin{array}{c}\text { Massive } \\
\text { timber }\end{array}$ & $\begin{array}{c}\text { Beam-and-column } \\
\text { timber }\end{array}$ & $\begin{array}{c}\text { Modular } \\
\text { timber }\end{array}$ \\
\hline Space heating & 18.5 & 18.8 & 18.8 & 18.8 & 18.8 \\
\hline Tap water heating & 15.0 & 15.0 & 15.0 & 15.0 & 15.0 \\
\hline Ventilation electricity & 5.1 & 5.1 & 5.1 & 5.1 & 5.1 \\
\hline Household electricity & 30.0 & 30.0 & 30.0 & 30.0 & 30.0 \\
\hline Facility electricity & 15.0 & 15.0 & 15.0 & 15.0 & 15.0 \\
\hline Total from operation & $\mathbf{8 3 . 6}$ & $\mathbf{8 3 . 9}$ & $\mathbf{8 3 . 9}$ & $\mathbf{8 3 . 9}$ & $\mathbf{8 3 . 9}$ \\
\hline
\end{tabular}

\begin{tabular}{|c|c|c|c|c|c|c|c|c|c|c|}
\hline \multirow[b]{2}{*}{ Description } & \multicolumn{5}{|c|}{ Primary energy use $\left(\mathrm{kWh} / \mathrm{m}^{2}\right)$} & \multicolumn{5}{|c|}{ GHG emission $\left(\mathrm{Kg} \mathrm{CO}_{2}\right.$-eq $\left./ \mathrm{m}^{2}\right)$} \\
\hline & $\begin{array}{c}\text { Rein- } \\
\text { forced } \\
\text { concrete }\end{array}$ & $\begin{array}{l}\text { Light- } \\
\text { frame } \\
\text { timber }\end{array}$ & $\begin{array}{c}\text { Massive } \\
\text { timber } \\
\text { frame }\end{array}$ & $\begin{array}{l}\text { Beam \& } \\
\text { column } \\
\text { timber }\end{array}$ & $\begin{array}{l}\text { Modu- } \\
\text { lar } \\
\text { timber }\end{array}$ & $\begin{array}{l}\text { Rein- } \\
\text { forced } \\
\text { concrete }\end{array}$ & $\begin{array}{l}\text { Light- } \\
\text { frame } \\
\text { timber }\end{array}$ & $\begin{array}{c}\text { Massive } \\
\text { timber } \\
\text { frame }\end{array}$ & $\begin{array}{c}\text { Beam \& } \\
\text { column } \\
\text { timber }\end{array}$ & $\begin{array}{l}\text { Mo- } \\
\text { dular } \\
\text { timber }\end{array}$ \\
\hline \multicolumn{11}{|c|}{ Heat pump heated: } \\
\hline $\begin{array}{l}\text { Space } \\
\text { heating }\end{array}$ & 19.0 & 19.3 & 19.3 & 19.3 & 19.3 & 0.7 & 0.7 & 0.7 & 0.7 & 0.7 \\
\hline $\begin{array}{l}\text { Tap water } \\
\text { heating }\end{array}$ & 15.4 & 15.4 & 15.4 & 15.4 & 15.4 & 0.6 & 0.6 & 0.6 & 0.6 & 0.6 \\
\hline $\begin{array}{l}\text { Ventilation } \\
\text { electricity }\end{array}$ & 13.4 & 13.4 & 13.4 & 13.4 & 13.4 & 0.5 & 0.5 & 0.5 & 0.5 & 0.5 \\
\hline $\begin{array}{l}\text { Household } \\
\text { electricity }\end{array}$ & 78.7 & 78.7 & 78.7 & 78.7 & 78.7 & 2.9 & 2.9 & 2.9 & 2.9 & 2.9 \\
\hline $\begin{array}{l}\text { Facility } \\
\text { electricity }\end{array}$ & 39.4 & 39.4 & 39.4 & 39.4 & 39.4 & 1.5 & 1.5 & 1.5 & 1.5 & 1.5 \\
\hline $\begin{array}{l}\text { Total from } \\
\text { operation }\end{array}$ & 165.9 & 166.2 & 166.2 & 166.2 & 166.2 & 6.1 & 6.1 & 6.1 & 6.1 & 6.1 \\
\hline \multicolumn{11}{|l|}{ District heated: } \\
\hline $\begin{array}{l}\text { Space } \\
\text { heating }\end{array}$ & 12.2 & 12.4 & 12.4 & 12.4 & 12.4 & 0.4 & 0.4 & 0.4 & 0.4 & 0.4 \\
\hline $\begin{array}{l}\text { Tap water } \\
\text { heating }\end{array}$ & 9.9 & 9.9 & 9.9 & 9.9 & 9.9 & 0.3 & 0.3 & 0.3 & 0.3 & 0.3 \\
\hline $\begin{array}{l}\text { Ventilation } \\
\text { electricity }\end{array}$ & 13.4 & 13.4 & 13.4 & 13.4 & 13.4 & 0.5 & 0.5 & 0.5 & 0.5 & 0.5 \\
\hline $\begin{array}{l}\text { Household } \\
\text { electricity }\end{array}$ & 78.7 & 78.7 & 78.7 & 78.7 & 78.7 & 2.9 & 2.9 & 2.9 & 2.9 & 2.9 \\
\hline $\begin{array}{l}\text { Facility } \\
\text { electricity }\end{array}$ & 39.4 & 39.4 & 39.4 & 39.4 & 39.4 & 1.5 & 1.5 & 1.5 & 1.5 & 1.5 \\
\hline $\begin{array}{l}\text { Total from } \\
\text { operation }\end{array}$ & 153.6 & 153.8 & 153.8 & 153.8 & 153.8 & 5.6 & 5.7 & 5.7 & 5.7 & 5.7 \\
\hline
\end{tabular}


The annual operation primary energy use and GHG emissions of the building versions located in Oslo and heated with different systems are shown in Table 6. The annual operation primary energy use and GHG emission are both reduced by between 7-8 \% when the buildings are heated with district heat instead of with electric-based heat pump.

Table 7 illustrates the primary energy and GHG balances for the end-of-life phase of the building versions. The primary energy and GHG benefits of demolished wood are considerable while recycling concrete results in small primary energy and GHG benefits. The benefit from recycling of concrete and steel are biggest for the reinforced concrete building systems.

\begin{tabular}{|c|c|c|c|c|c|c|c|c|c|c|}
\hline \multirow[b]{2}{*}{ Description } & \multicolumn{5}{|c|}{ Primary energy use $\left(\mathrm{kWh} / \mathrm{m}^{2}\right)$} & \multicolumn{5}{|c|}{ GHG emission $\left(\mathrm{Kg} \mathrm{CO}_{2}\right.$-eq $\left./ \mathrm{m}^{2}\right)$} \\
\hline & $\begin{array}{l}\text { Rein- } \\
\text { forced } \\
\text { concrete }\end{array}$ & $\begin{array}{l}\text { Light- } \\
\text { frame } \\
\text { timber }\end{array}$ & $\begin{array}{l}\text { Massive } \\
\text { timber } \\
\text { frame }\end{array}$ & $\begin{array}{l}\text { Beam \& } \\
\text { column } \\
\text { timber }\end{array}$ & $\begin{array}{l}\text { Mo- } \\
\text { dular } \\
\text { timber }\end{array}$ & $\begin{array}{l}\text { Rein- } \\
\text { forced } \\
\text { concrete }\end{array}$ & $\begin{array}{l}\text { Light- } \\
\text { frame } \\
\text { timber }\end{array}$ & $\begin{array}{c}\text { Massive } \\
\text { timber } \\
\text { frame }\end{array}$ & $\begin{array}{l}\text { Beam \& } \\
\text { column } \\
\text { timber }\end{array}$ & $\begin{array}{l}\text { Mo- } \\
\text { dular } \\
\text { timber }\end{array}$ \\
\hline $\begin{array}{l}\text { Demolition } \\
\text { energy }\end{array}$ & 20 & 10 & 10 & 10 & 10 & 6 & 3 & 3 & 3 & 3 \\
\hline \multicolumn{11}{|l|}{$\begin{array}{l}\text { End-of-life } \\
\text { benefits: }\end{array}$} \\
\hline $\begin{array}{l}\text { Concrete } \\
\text { recycling }\end{array}$ & -19 & -3 & -2 & -2 & -2 & -7 & -1 & -1 & -1 & -1 \\
\hline $\begin{array}{l}\text { Steel } \\
\text { recycling }\end{array}$ & -96 & -60 & -14 & -35 & -10 & -34 & -21 & -12 & -12 & -3 \\
\hline $\begin{array}{l}\text { Wood } \\
\text { recovery for } \\
\text { bioenergy }\end{array}$ & -220 & -340 & -502 & -441 & -385 & -85 & -123 & -203 & -178 & -156 \\
\hline Total & -315 & -393 & -508 & -468 & -387 & -120 & -142 & -213 & -188 & -157 \\
\hline
\end{tabular}

Fig. 3 shows the primary energy and GHG emissions for production, space heating and ventilation during 50 years, and end-of-life for the buildings when heated with district heating. The operation phase dominates the lifecycle primary energy use of the building systems. Material

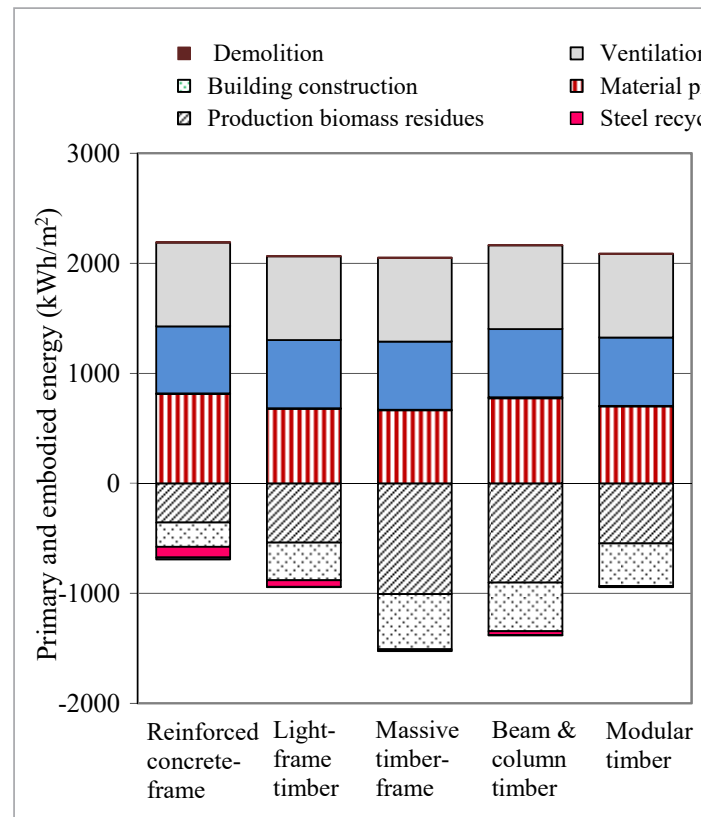

$\square$ Space heating

- Demolition wood

$\square$ Concrete recycling and carbonation

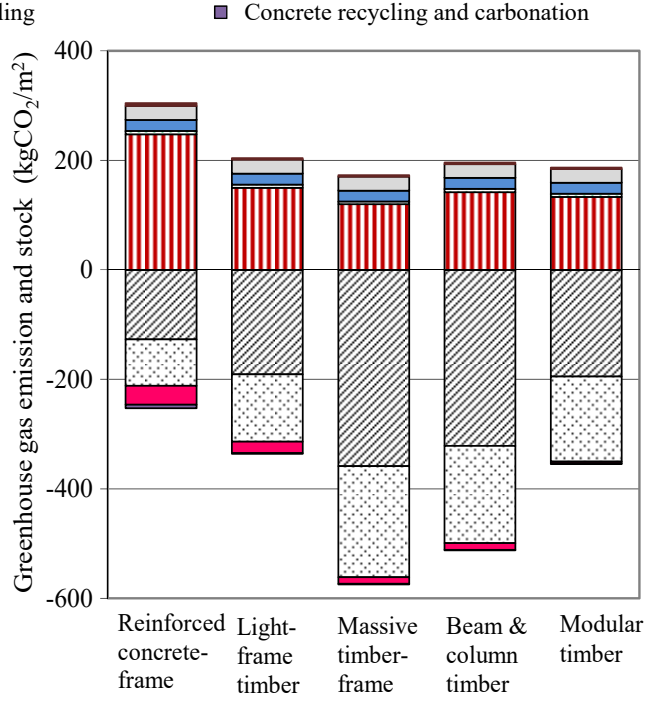

\section{Table 7}

Primary energy and GHG balances for endof-life management of the buildings
Fig. 3

Primary energy use (left) and GHG emissions (right) for the lifecycle phases of the district heated buildings for the 50-year period 
production accounts for a large share of the lifecycle GHG emission for the buildings as heat supply is from biomass-based district heating. Overall, the timber-based building systems have negative net GHG balances over their complete lifecycle due to the benefits of recovery of production biomass residues for use as fuel and the recovery as well as recycling of the end-of-life materials. The massive timber building gives the lowest lifecycle primary energy use and GHG emission while the reinforced concrete building results in the greatest lifecycle impacts among the analysed building systems.

This study has explored the lifecycle primary energy and GHG implications of conventional and modern multi-storey building systems designed to the Norwegian passive house criteria with different structural frame materials. The explored buildings have concrete or timber structural framework and the analysis covered the production, operation and end-of-life phases. The analysis shows that the choice of structural frame material as well as building system has significant effect on the primary energy use and climate impact of buildings. The primary energy for building production is 4-18\% lower for the analysed timber-based building systems compared to the reinforced concrete building alternative. Correspondingly, the timber-based building systems give 39-51\% lower GHG emissions for building production in contrast to the reinforced concrete building alternative. This finding corroborates current findings in literature e.g. Gustavsson et al. (2006) and Dodoo et al. (2009).

The operation phase dominates the lifecycle primary energy use of the buildings and the reinforced concrete-frame building gives about $0.2 \%$ lower space heating primary energy demand compared to the timber-based building systems, due to the benefits of thermal mass. The operation primary energy use and GHG emissions for the buildings are lower when heated with cogenerated district heating compared to when heated with electric-based heat pump, showing the importance of heat supply system. Large amounts of biomass residues are produced for the timber-based building systems and the energy content of the residues is significant relative to the primary energy used for production of the timber-based building systems. For the massive timber and beam-and-column timber systems, the energy content of the recoverable residues more than offset the primary energy required for material production and construction process. In contrast to the post-use steel and concrete materials, the end-of-life management for the wood-based material resulted in significant primary energy and GHG benefits.

The lifecycle impacts are lower for the timber-based building systems than for the reinforced concrete building system, due primarily to the lower production primary energy as well as fossil energy use, and greater amount of biomass residues when using wood materials. These advantages more than outweigh the energy saving benefits of thermal mass of the concrete structure. The massive timber building system gives the lowest lifecycle primary energy and GHG balances. Except for the modular timber-frame building system, the modern building systems outperform the conventional alternative building systems in terms of lifecycle primary energy use and GHG emissions.

\section{Conclusions}

The results of this study show that overall lifecycle impacts, including primary energy use and GHG emission for production, operation and end-of-life management are lower for timber-frame buildings than for alternative building with reinforced concrete-frame. This is due mainly to the lower production primary energy use and GHG emissions, and also greater amount of biomass residues recoverable from the wood product chain.

This analysis indicates that choice of heat supply system has significant effect on the life cycle impact of buildings. In summary, timber-based buildings and efficient heat supply systems are 
of great importance for a low energy building and should be an integral part of the effort to create a resource efficient low carbon built environment.

Adalberth, K., Almgren, A. \& Petersen, E. H. Life-cycle assessment of four multi-family buildings. International Journal of Low Energy \& Sustainable Buildings, 2001.

Aye, L., Ngo, T., Crawford, R., Gammampila, R. \& Mendis, P. Life cycle greenhouse gas emissions and energy analysis of prefabricated reusable building modules. Energy \& Buildings, 2012, 47: 159-168. https://doi.org/10.1016/j.enbuild.2011.11.049

Bergseng, E., Eid, T., Løken, Ø. \& Astrup, R. Harvest residue potential in norway-A bio-economic model appraisal. Scandinavian Journal of Forest Research, 2013, 28, 470-480. https://doi.org/10.10 80/02827581.2013.766259

Björklund, T. \& Tillman, A.-M. LCA of building frame structures: environmetal impact over the life cycle of wooden and concrete frames; 1997.

BP. BP Energy Outlook, 2018. Available at https:// www.bp.com.

Cabeza, L. F., Rincón, L., Vilari-o, V., Pérez, G. \& Castell, A. Life cycle assessment (LCA) and life cycle energy analysis (LCEA) of buildings and the building sector: A review. Renewable \& Sustainable Energy Reviews, 2014, 29: 394-416. https://doi. org/10.1016/j.rser.2013.08.037

Dahlstrøm, O., Sørnes, K., Eriksen, S. T. \& Hertwich, E. G. Life cycle assessment of a single-family residence built to either conventional-or passive house standard. Energy \& buildings, 2012, 54: 470-479.

Dodoo, A., Gustavsson, L. \& Sathre, R. Carbon implications of end-of-life management of building materials. Resources, Conservation \& Recycling, 2009, 53: 276-286. https://doi.org/10.1016/j.resconrec.2008.12.007

Ecoinvent, The Ecoinvent database, 2012.

Fossdal, S. Energi-og Miljøregnskap for bygg (Energy and environmental accounts of building construction). Report 173, The Norwegian Institute of Building Research, Oslo; 1995.

Gustavsson, L., Joelsson, A. \& Sathre, R. Life cycle primary energy use and carbon emission of an eight-storey wood-framed apartment building. Energy \& Buildings, 2010, 42: 230-242. https://doi. org/10.1016/j.enbuild.2009.08.018

Gustavsson, L. \& Karlsson, Å. CO2 mitigation: on methods and parameters for comparison of fos- sil-fuel and biofuel systems. Mitigation \& AdaptaReferences 959. https://doi.org/10.1007/s1 1027-006-9028-7

Gustavsson, L., Pingoud, K. \& Sathre, R. Carbon dioxide balance of wood substitution: comparing concrete-and wood-framed buildings. Mitigation and adaptation strategies for global change, 2006, 11: 667-691. https://doi.org/10.1007/s11027-0067207-1

Gustavsson, L. \& Sathre, R. Variability in energy and carbon dioxide balances of wood and concrete building materials. Building and Environment, 2006, 41:940-951. https://doi.org/10.1016/j.buildenv.2005.04.008

IEA. Key world energy statistics, International Energy Agency; 2018a.

IEA. Buildings. International Energy Agency; 2018b. Available at https://www.iea.org/buildings/.

IPCC Climate Change 2014: Mitigation of Climate Change. Contribution of Working Group III to the Fifth Assessment Report of the Intergovernmental Panel on Climate Change; 2014.

Karlsson, Å. ENSYST, Version 1.2. Lund University, Lund; 2003.

Kua, H. W. \& Kamath, S. An attributional and consequential life cycle assessment of substituting concrete with bricks. Journal of Cleaner Production, 2014, 81: 190-200. https://doi.org/10.1016/j. jclepro.2014.06.006

NS 3700. Criteria for passive and low energy residential buildings, Norwegian Standard; 2013.

Persson, S. Wälludden trähus i fem våningar: Erfarenheter och lärdomar, Tekniska Högskolan i Lund, Avdelningen för Bärande Konstruktioner, Lund; 1998.

Plevin, R. J., Delucchi, M. A. \& Creutzig, F. Using attributional life cycle assessment to estimate climate-change mitigation benefits misleads policy makers. Journal of IndustrialEcology, 2014, 18:73-83. https://doi.org/10.1111/jiec.12074

Ramesh, T., Prakash, R. \& Shukla, K. Life cycle energy analysis of buildings: An overview. Energy \& Buildings, 2010, 42: 1592-1600. https://doi. org/10.1016/j.enbuild.2010.05.007

StruSoft. VIP-Energy software, Sweden; 2010. Available from http://www.strusoft.com on 10/01/2017. 
Suzuki, M., Oka, T. \& Okada, K. The estimation of energy consumption and $\mathrm{CO} 2$ emission due to housing construction in Japan. Energy \& Buildings, 1995, 22:165169. https://doi.org/10.1016/0378-7788(95)00914-J

TEK 10. Norwegian building code, 2010. Available at http://dibk.no

Tettey, U. Y. A., Dodoo, A. \& Gustavsson, L. Effects of different insulation materials on primary ener- gy and CO2 emission of a multi-storey residential building. Energy \& Buildings, 2014, 82: 369-377. https://doi.org/10.1016/j.enbuild.2014.07.009

Thormark, C. A low energy building in a life cycle-its embodied energy, energy need for operation and recycling potential. Building \& environment, 2002, 37: 429-435. https://doi.org/10.1016/S03601323(01)00033-6

\section{About the Author \\ AMBROSE DODOO \\ Associate Professor \\ Linnaeus University, Department of Building Technology \\ Main research area \\ Life cycle analysis, building simulation, HVAC systems analysis, building technology \\ Address \\ Georg Lückligs 1, Växjö, SE-35195, Sweden Tel. 0046 (0) 470767812 \\ E-mail: ambrose.dodoo@lnu.se}

